Document downloaded from:

http://hdl.handle.net/10251/37509

This paper must be cited as:

Moragues Pons, ME.; Santos Figueroa, LE.; Abalos Aguado, T.; Sancenón Galarza, F.; Martínez Mañez, R. (2012). Synthesis of a new tripodal chemosensor based on 2,4,6triethyl-1,3,5-trimethylbencene scaffolding bearing thiourea and fluorescein for the chromofluorogenic detection of anions. Tetrahedron Letters. 53(38):5110-5113. doi:10.1016/j.tetlet.2012.07.039.

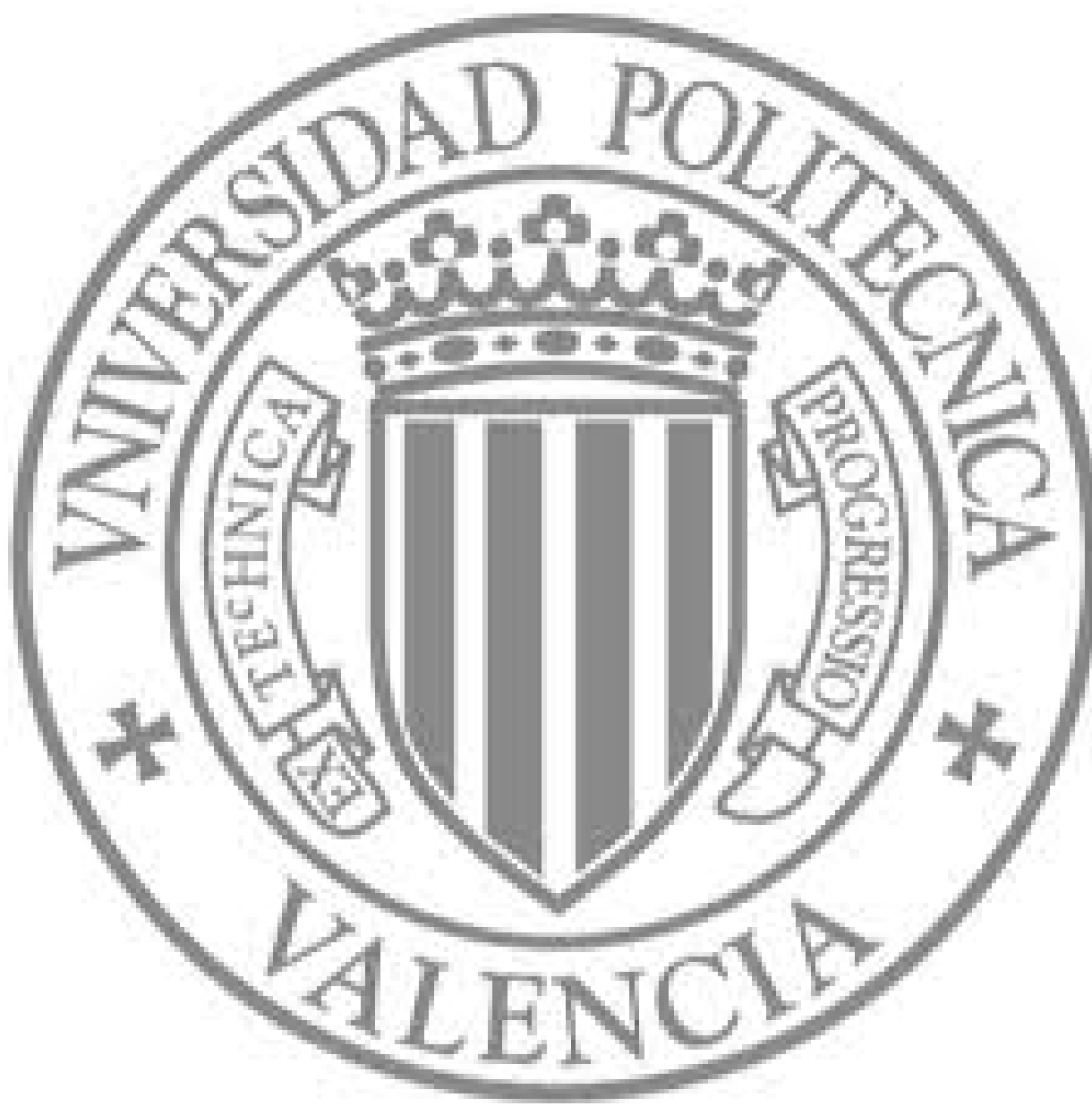

The final publication is available at

http://dx.doi.org/10.1016/j.tetlet.2012.07.039

Copyright Elsevier 


\title{
Synthesis of a new tripodal chemosensor based on 2,4,6-triethyl- 1,3,5-trimethylbencene scaffolding bearing thiourea and fluorescein for the chromo-fluorogenic detection of anions
}

\author{
María E. Moragues, Luis E. Santos-Figueroa, Tatiana Ábalos, Félix Sancenón* and Ramón \\ Martínez-Máñez ${ }^{*}$
}

Centro de Reconocimiento Molecular y Desarrollo Tecnológico (IDM), Unidad Mixta Universidad Politécnica de Valencia-Universidad de Valencia, Camino de Vera s/n, 46022, Valencia, Spain. CIBER de Bioingeniería, Biomaterailes y Nanomedicina (CIBER-BBN).

\begin{abstract}
A tripodal receptor containing thiourea as binding site and fluorescein as signalling subunit has been designed, synthesized and used for the colorimetric detection of basic anions in DMSO solutions. (C) 2014 Elsevier Science. All rights reserved
\end{abstract}

\begin{abstract}
${ }^{1}$ The design of abiotic anion receptors able to display sensing features have attracted increasing attentions due to the key roles played by these negatively charged species in chemical, biological and environmental processes. ${ }^{1}$ Host molecules generally comprise two subunits, i.e. the "binding site" (properly the host, responsible of coordination event) and the "signalling subunit" (in charge of the transduction event) that are usually attached forming a superstructure. ${ }^{2}$ In these signaling systems optical outputs are especially attractive with respect to other possible transductions of the signal, because detection uses cheap, easy-to-handle and widely extended instrumentation. Apart from fluorescence systems, colorimetric recognition has become more and more popular because it additionally offers the opportunity to develop signaling systems for the "naked eye" detection of target species.
\end{abstract}

During the last years, a large number of receptors using groups, such as amide, ${ }^{3}$ urea, ${ }^{4}$ thiourea, ${ }^{5}$ sulfonamide, ${ }^{6}$ pyrrole $^{7}$ and indole, ${ }^{8}$ which give hydrogen bonding interactions with anions, have been reported and have been adequately coupled with different signalling reporters. Moreover this approach is usually related with the design and covalent link of the binding site and the signalling subunit in a pre-determined fashion. Anion binding hosts may also be designed on the basis of their flexibility or degree of pre-organization. These concepts have been crystallised in many cases via the design of receptors showing multiple coordination sites in a pre-defined fashion. For instance, some remarkable examples involve the development of anion receptors based on 1,3,5-2,4,6 functionalized benzene scaffoldings with 1,3,5-positions directed to one face of the ring in order to prepare trifurcate anion receptors containing three arms with coordinating groups in cooperative mode. ${ }^{9}$

Keywords: Chromogenic chemosensors; anion recognition; tripodal receptor; prearranged scaffolds.

${ }^{*}$ Corresponding author. Tel.: +34-963877343; fax: +34-963879349; RMM e-mail: rmaez@qim.upv.es. FS e-mail: fsanceno@upvnet.upv.es.
Scheme 1. Synthesis of receptor 3. Reagents and conditions: (i) 1) paraformaldehyde $-\mathrm{ZnBr}_{2}-\mathrm{HBr} / \mathrm{AcOH}-90^{\circ} \mathrm{C}$; 2) potassium phthalimidedry DMSO- $\left.90^{\circ} \mathrm{C} ; 3\right)$ hydrazine hydrate-EtOH/toluene $(2: 1)-$ reflux $^{11}$; (ii)
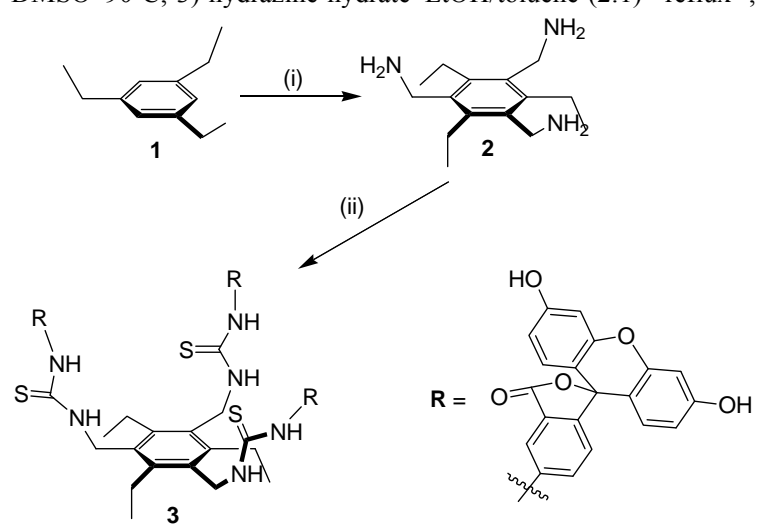

fluorescein isothiocyanate- $\mathrm{CH}_{2} \mathrm{Cl}_{2}$-triethylamine-reflux.

Following our interest in the development of anion chemosensors, ${ }^{10}$ we report herein the synthesis of an acyclic tripodal receptor based on a 1,3,5-trisubstituted2,4,6-triethylbenzene scaffold. The host molecule 3 contains thiourea binding sites and fluorescein groups as signalling subunits. The chromogenic and fluorogenic behaviour of receptor 3 was tested against certain selected anions in organic and organic-water mixed solutions.

The synthesis of tripodal 1,3,5-trimethylamino-2,4,6triethylbenzene (2) has been published elsewere. ${ }^{11}$ Reaction of 2 with fluorescein isothiocyanate and catalytic amounts of triethylamine in refluxing $\mathrm{CH}_{2} \mathrm{Cl}_{2}$ afforded receptor 3 (see Scheme 1) in moderate yield as an orange solid. The ${ }^{1} \mathrm{H}$ NMR spectra of tripodal receptor 3 was characterized by the presence of two signals at 1.15 and $2.95 \mathrm{ppm}$ attributed to the three ethyl moieties and one singlet at 4.67 ppm ascribable to the six methylene protons that linked the three thiourea moieties with the benzene ring. The aromatic signals of the three fluorescein moieties appeared in the 
5.12-8.5 ppm interval, whereas the thiourea protons appeared at 8.1 and 8.25 ppm as broad singlets. ${ }^{12}$

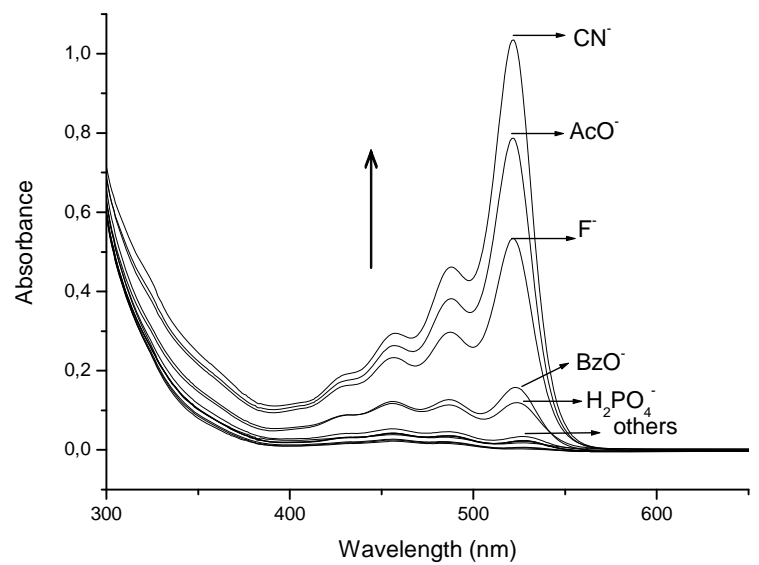

Figure 1. Changes in the UV-visible spectra of receptor $3\left(5.0 \times 10^{-5} \mathrm{~mol}\right.$ $\mathrm{dm}^{-3}$ ) in DMSO after addition of 1 eq. of selected anions.

The UV-visible response of receptor 3 in the presence of selected anions was tested in DMSO. DMSO solution of receptor $3\left(5.0 \times 10^{-5} \mathrm{~mol} \mathrm{\textrm {dm } ^ { - 3 }}\right)$ showed very weak absorption bands (centred at 432, 457, 486 and $528 \mathrm{~nm}$ ) in the visible zone (see Figure 1). From previous studies on fluorescein derivatives, ${ }^{13}$ the absence of colour suggested that the colourless cyclic lactone form of fluorescein is the predominant isomer in receptor 3 in DMSO solution.

In a further step, the UV-visible response of receptor 3 was tested against several anions $\left(\mathrm{CN}^{-}, \mathrm{F}^{-}, \mathrm{Cl}^{-}, \mathrm{Br}^{-}, \mathrm{I}^{-}, \mathrm{NO}_{3}{ }^{-}\right.$, $\mathrm{H}_{2} \mathrm{PO}_{4}{ }^{-}, \mathrm{HSO}_{4}^{-}, \mathrm{ClO}_{4}^{-}, \mathrm{AcO}^{-}, \mathrm{BzO}^{-}$and $\left.\mathrm{Cit}^{3-}\right)$. The response of 3 in the presence of 1 equivalent of the selected anions can be seen in Figure 1. Addition of $\mathrm{Cl}^{-}, \mathrm{Br}^{-}, \mathrm{I}^{-}, \mathrm{NO}_{3}{ }^{-}$, $\mathrm{HSO}_{4}^{-}, \mathrm{ClO}_{4}^{-}$and $\mathrm{Cit}^{3-}$ induced negligible changes in the UV-visible profiles, whereas $\mathrm{H}_{2} \mathrm{PO}_{4}^{-}$and $\mathrm{BzO}^{-}$promoted a small increase in the absorbance of the visible bands. However, the most remarkable changes were observed upon addition of $\mathrm{CN}^{-}, \mathrm{F}^{-}$and $\mathrm{AcO}^{-}$for which the absorbances of the four visible bands were highly enhanced. These changes were reflected in colour modulations from colourless to bright orange (see Figure 2a and $2 \mathrm{~b}$ ). These bands in the $400-550 \mathrm{~nm}$ range can be attributed to the presence of the open form of the fluorescein dye. A remarkable enhancement of the fluorescence was also observed (see Figure 2c).

Figure 2. Colour change observed for chemosensor $3\left(2.70 \times 10^{-5} \mathrm{~mol} \mathrm{dm}\right.$ ${ }^{3}$ ) in DMSO upon addition of: a) 4 eq. and b) 10 eq. of various anions as tetrabutylammonium salts at room temperature; c) Fluorescence emission of DMSO solutions of receptor 3 with 10 eq. of anions when irradiating at $365 \mathrm{~nm}$.

Titration profiles of receptor 3 upon addition of increasing quantities of $\mathrm{CN}^{-}, \mathrm{F}^{-}, \mathrm{H}_{2} \mathrm{PO}_{4}^{-}, \mathrm{AcO}^{-}$and $\mathrm{BzO}^{-}$anions were carried out. Figure 3 shows the visible spectral changes of receptor 3 in DMSO solution $\left(5.0 \times 10^{-5} \mathrm{~mol} \mathrm{dm}^{-3}\right)$ upon addition of increasing quantities of $\mathrm{AcO}^{-}$anion (from 0.2 to 10 eq.), as well as the non-linear curve fitting of the absorbance band centred at ca. $520 \mathrm{~nm}$. As it can be seen a clear and gradual absorbance enhancement of the visible band was observed. The best fitting of the titration data was obtained bearing in mind the presence of two processes, namely the formation of hydrogen-bonded complexes of 1:1 stoichiometry between 3 and the anion (1) and a deprotonation reaction upon addition of excess of anion (2):

$$
\begin{aligned}
& 3+\mathrm{A}^{-} \leftrightarrows 3-\mathrm{A}^{-} \\
& 3-\mathrm{A}^{-}+\mathrm{A}^{-} \leftrightarrows 3^{-}+\mathrm{HA}_{2}^{-} \\
& 3+2 \mathrm{~A}^{-} \leftrightarrows 3^{-}+\mathrm{HA}_{2}^{-}
\end{aligned}
$$

This set of spectra allowed us to determine the strength of the interaction through the calculation of the stability constants for the formation of the corresponding complex between receptor 3 and $\mathrm{AcO}^{-}$anion and for the deprotonation step (see Table 1 and global equilibrium (3)).

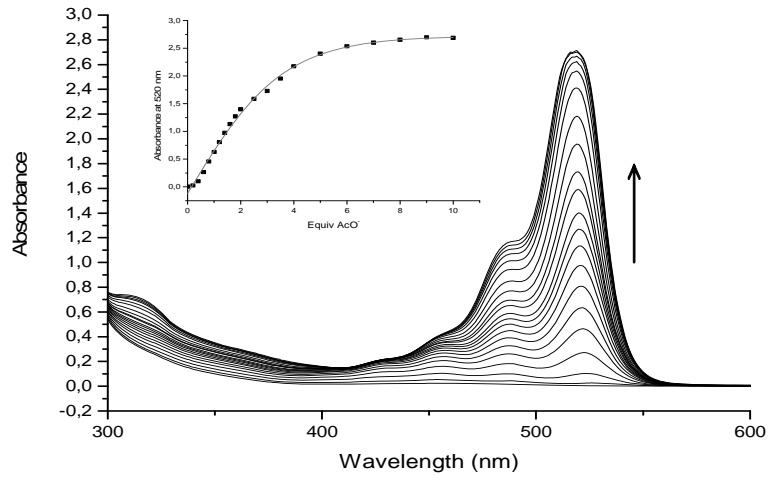

Figure 3. UV-visible spectral changes of receptor $3\left(5.0 \times 10^{-5} \mathrm{~mol} \mathrm{dm}^{-3}\right)$ in DMSO upon addition of $\mathrm{AcO}^{-}(0.2-10$ eq.). The inset shows the nonlinear curve fitting of the absorbance at $520 \mathrm{~nm}$ against the added $\mathrm{AcO}^{-}$.

The titration profiles of receptor 3 upon addition of $\mathrm{CN}^{-}$ and $\mathrm{F}^{-}$anion induced similar absorption enhancements to those observed upon addition of $\mathrm{AcO}^{-}$and allowed us fit the experimental data to the two step mechanism (see also Table 1). The changes in the visible zone upon addition of $\mathrm{H}_{2} \mathrm{PO}_{4}{ }^{-}$and $\mathrm{BzO}^{-}$anions were less pronounced (see Figure 4 for $\mathrm{BzO}^{-}$anion and also Table 1 for the stability constants) reflecting the lower interaction of these anions with 3 when compared with $\mathrm{CN}^{-}, \mathrm{F}^{-}$and $\mathrm{AcO}^{-}$. The chromogenic response of receptor $\mathbf{3}$ is clearly related with the basicity of the tested anions and it was clear from the results that an increase of the basicity of the anion $\left(\mathrm{CN}^{-} \approx\right.$ $\left.\mathrm{F}^{-}>\mathrm{AcO}^{-}>\mathrm{BzO}^{-}>\mathrm{H}_{2} \mathrm{PO}_{4}^{-}\right)$was directly reflected in a larger enhancement of the intensity of the visible bands and also in an enhancement of the fluorescence. In fact the same colour modulation and fluorescence enhancement was observed upon titration of $\mathbf{3}$ in DMSO with tetrabutylammonium hydroxide. 


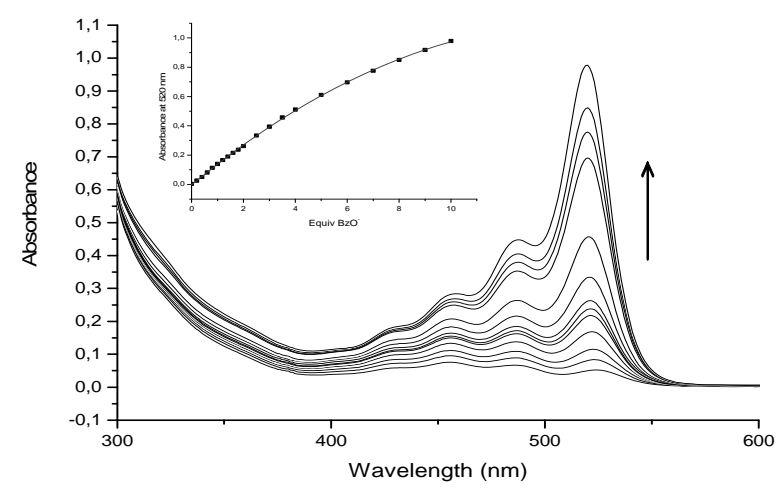

Figure 4. UV-visible spectral changes of $3\left(5.0 \times 10^{-5} \mathrm{~mol} \mathrm{dm}^{-3}\right)$ in DMSO upon addition of $\mathrm{BzO}^{-}(0.2-10$ eq.) anion. The inset shows the nonlinear curve fitting of the absorbance at $520 \mathrm{~nm}$ against the added $\mathrm{BzO}^{-}$.

Table 1. Acidity constants for the interaction of receptor 3 with some anions in DMSO.

\begin{tabular}{ccc}
\hline Anion & Interaction & $\log \beta^{\mathrm{a}}$ \\
\hline $\mathrm{OH}^{-}$ & $(1: 2)$ & $12.73 \pm 0.47$ \\
$\mathrm{CN}^{-}$ & $(1: 2)$ & $7.99 \pm 0.52$ \\
$\mathrm{~F}^{-}$ & $(1: 2)$ & $6.99 \pm 0.85$ \\
$\mathrm{AcO}^{-}$ & $(1: 2)$ & $4.00 \pm 0.44$ \\
$\mathrm{BzO}^{-}$ & $(1: 2)$ & $2.77 \pm 0.16$ \\
$\mathrm{H}_{2} \mathrm{PO}_{4}^{-}$ & $(1: 2)$ & $\mathrm{ND}^{\mathrm{b}}$ \\
\hline
\end{tabular}

${ }^{\mathrm{a}}$ Calculated using the program HypSpec 1.1.18.

${ }^{\mathrm{b}}$ The spectral changes were too small to calculate binding constant.

The logarithms of the stability constants of the coordination process are small, ranging from -9.31 for $\mathrm{OH}^{-}$to -0.27 for $\mathrm{AcO}^{-}$, whereas the constants for the deprotonation process are bigger (12.73 for $\mathrm{OH}^{-}$and 4.00 for $\left.\mathrm{AcO}^{-}\right)$. This fact clearly indicated a neat proton transfer reaction between 3 and $\mathrm{OH}^{-}$anion whereas the other anions formed hydrogenbonding complexes (with the thiourea binding sites) with 1:1 stoichiometries at low anion concentrations. Upon addition of increasing quantities of anions a deprotonation process occurs, the intensity of which is clearly related with the basicity of the anion (see Table 1).

The enhancement of the absorption and the fluorescence observed in the presence of basic anions suggested that the sensing mechanism would most likely involve the deprotonation of the hydroxyl moieties that induced the opening of the lactone ring in the fluorescein chromophore. The fact that the same chromo-fluorogenic response was observed upon addition of increasing quantities of fluoride anion to colourless DMSO solutions of fluorescein corroborates the proposed mechanism.

Additional studies were also carried out with DMSO-water 90:10 v/v solutions ( $\mathrm{pH} 7.0)$ of receptor $3\left(5.0 \times 10^{-5} \mathrm{~mol}\right.$ $\mathrm{dm}^{-3}$ ) in order to test the possible application for anion sensing in aqueous medium. Addition of $\mathrm{CN}^{-}, \mathrm{F}^{-}, \mathrm{H}_{2} \mathrm{PO}_{4}^{-}$, $\mathrm{AcO}^{-}$and $\mathrm{BzO}^{-}$anions to DMSO-water solutions of 3 resulted in same changes on the UV-visible spectrum than the observed when using DMSO alone. The only difference was related with the fact that more equivalents of the anions were necessary to obtain the same change in the absorbance. This is a clear consequence of the partial solvation of the anion in the presence of water that reduced their basicity.

In summary, we have synthesized a new tripodal chemosensor containing thiourea binding sites and fluorescein as signalling reporter for the colorimetric detection of basic anions in DMSO and mixed waterDMSO solutions. The colorimetric response observed is due to the opening of the lactone ring of fluorescein induced by the deprotonation of the hydroxyl moieties.

\section{Acknowledgments}

Financial support from the Spanish Government (project MAT2009-14564-C04-01) and the Generalitat Valenciana (project PROMETEO/2009/016) is gratefully acknowledged. MEM thanks the Ministerio de Educación for a Doctoral FPU Fellowship.

\section{References}

1. (a) Schmdtchen, F.P.; Berger, M. Chem. Rev. 1997, 97, 16091646; (b) Beer, P. D.; Gale, P. A. Angew. Chem. Int. Ed. 2001, 40, 486-516; (c) Wenzel, M.; Hiscock, J.R.; Gale, P.A. Chem. Soc. Rev. 2012, 41(1), 480-520; (d) Suksai, C.; Tuntulani, T. Chem. Soc. Rev. 2003, 32, 192-202; (e) Gunnlaugsson, T.; Glynn, M.; Tocci, G.M.; Kruger; P.E.; Pfeffer, F.M. Coord. Chem. Rev. 2006, 250, 3094-3117.

2. (a) Moragues, M.E.; Martínez-Máñez, R.; Sancenón, F. Chem. Soc. Rev. 2011, 40, 2593-2643; (b) Martínez-Máñez, R.; Sancenón, F. Chem. Rev. 2003, 103, 4419-4476; (c) Martínez-Máñez, R.; Sancenón, F. Coord. Chem. Rev. 2006, 250, 3081-3093; (d) Wiskur, S. L.; Aït-Haddou, H.; Lavigne, J. J.; Anslyn, E. V. Acc. Chem. Res. 2001, 34, 963-972; (e) Amendola, V.; Esteban-Gómez, D.; Fabbrizzi, L.; Lichelli, M. Acc. Chem. Res. 2006, 39, 343-348.

3. (a) Kang, J.; Jo, J. H.; In, S. Tetrahedron Lett. 2004, 45, 5225-5228; (b) Chmielewski, M.; Jurczak, J. Tetrahedron Lett. 2004, 45, 6007-6010; (c) Chmielewski, M.; Jurczak, J. Tetrahedron Lett. 2005, 46, 3085-3088; (d) Choi, K.; Hamilton, A. D. Coord. Chem. Rev. 2003, 240, 101-110; (e) Evans, L.S.; Gale, P.A. Chem. Commun. 2004, 1286-1287.

4. (a) Cho, E.J.; Ryu, B.J.; Lee, Y.J.; Nam, K.C. Org. Lett. 2005, 7, 2607-2609; (b) Burns, D.H.; Calderon-Kawasaki, K.; Kularatne, S. J. Org. Chem. 2005, 70, 2803-2807; (c) Bao, X.P.; Zhang, H.; Zhang, Z.; Wu, L.; Li. Z.Y. Inorg. Chem. Commun. 2007, 10, 728-729; (d) Esteban-Gómez, D.; Fabbrizzi, L.; Licchelli, M.; Monzani, E. Org. Biomol. Chem. 2005, 3, 1495-1500; (e) Loeb, S.J. J. Am. Chem. Soc. 2004, 126, 5030-5031.

5. (a) Kato, R.; Nishizawa, S.; Hayashita, T.; Teramae, N. Tetrahedron Lett. 2001, 42, 5053-5056; (b) Kondo, S.I.; Nagamine, M.; Yano, Y. Tetrahedron Lett. 2003, 44, 88018804; (c) Bao, X.P.; Wang, L.; Wu, L.; Li. Z.Y. Supramol. Chem. 2008, 20, 467-478; (d) Gunnlaugsson, T.; Davis, A.P.; O'Brien, J.E.; Glynn, M. Org. Biomol. Chem. 2005, 3, 48-56; (e) Jun, E.J.; Swamy, K.M.K.; Bang, H.; Kim, S-J.; Yoon, J. Tetrahedron Lett. 2006, 47, 3103-3106.

6. (a) Starnes, S.D.; Arungundram, S.; Saunders, C.H. Tetrahedron Lett. 2002, 43, 7785-7788; (b) Chung, Y.M.; Raman, B.; Kim, D.S.; Ahn, K.H. Chem. Commun. 2006, 186-188.

7. (a) Black, C.B.; Andrioletti, B.; Try, A.C.; Ruiperez, C.; Sessler, J.L. J. Am. Chem. Soc. 1999, 121, 10438-10439; (b) Sessler, J.L.; Maeda, H.; Mizuno, T.; Lynch, V.M.; Furuta, H. 
Chem. Commun. 2002, 862-863; (c) Sessler, J.L.; Pantos, G.D.; Katayev, E.; Lynch, V.M. Org. Lett. 2003, 5, 41414144; (d) Gale, P.A.; Light, M.E.; McNally, B.; Navakhun, K.; Sliwinski, K.E.; Smith, B.D. Chem. Commun. 2005, 3773-3775.

8. (a) Chang, K.J.; Moon, D.; Lah, M.S.; Jeong, K.S. Angew. Chem. Int. Ed. 2005, 44, 7926-7929; (b) Kim, N.K.; Chang, K.J.; Moon, D.; Lah, M.S.; Jeong, K.S. Chem. Commun. 2007, 3401-3403; (c) Yu, J.O.; Browning, C.S.; Farrar, D.H. Chem. Commun. 2008, 1020-1022.

9. (a) Metzger, A.; Anslyn, E. V. Angew. Chem. Int. Ed. 1998, 37, 649-652; (b) Wiskur, S. L.; Anslyn, E. V. J. Am. Chem. Soc. 2001, 123, 10109-10110; (c) Aït-Haddou, H.; Wiskur, S. L.; Lynch, V. M.; Anslyn, E. V. J. Am. Chem. Soc. 2001, 123, 11296-11297.

10. For recent works on anion chemosensors see for example: (a) Climent, E.; Giménez, C.; Marcos, M. D.; Martínez-Máñez, R.; Sancenón, F.; Soto, J. Chem. Commun. 2011, 47, 68736875; (b) Calero, P.; Hecht, M.; Martínez-Máñez, R.; Sancenón, F.; Soto, J.; Vivancos, J. L.; Rurack, K. Chem. Commun. 2011, 47, 10599-10601; (c) Ábalos, T.; Jiménez, D.; Moragues, M.; Royo, S.; Martínez-Máñez, R.; Sancenón, F.; Soto, J.; Costero, A. M.; Parra, M.; Gil, S. Dalton Trans. 2010, 39, 3449-3459; (d) Climent, E.; Calero, P.; Marcos, M. D.; Martínez-Máñez, R.; Sancenón, F.; Soto, J. Chem. Eur. J. 2009, 15, 1816-1820; (e) Ábalos, T.; Royo, S.; MartínezMáñez, R.; Sancenón, F.; Soto, J.; Costero, A. M.; Gil, S.; Parra, M. New J. Chem. 2009, 33, 1641-1645; (f) Comes, M.; Marcos, M. D.; Martínez-Máñez, R.; Sancenón, F.; Soto, J.; Villaescusa, L. A.; Amorós, P. Chem. Commun. 2008, 36393641.

11. Vacca, A.; Nativi, C.; Cacciarini, M.; Pergoli, R.; Roelens, S. J. Am. Chem. Soc. 2004, 126, 16456-16464.

12. Synthesis of compound 2: In a first step, to a mixture of paraformaldehyde $(16.7 \mathrm{~g}, 556.3 \mathrm{mmol})$ and triethylbenzene $(1,10 \mathrm{~mL}, 53.1 \mathrm{mmol})$ in $\mathrm{HBr} / \mathrm{AcOH}(100 \mathrm{~mL}, 30 \mathrm{wt} \%)$ zinc bromide $(19.7 \mathrm{~g}, 87.5 \mathrm{mmol})$ was slowly added at room temperature. The mixture was heated to $90{ }^{\circ} \mathrm{C}$ for $16.5 \mathrm{~h}$, during which time white crystals were formed. The reaction was cooled to room temperature, and the white solid was filtered off, washed with water, and dried under vacuum overnight to give 1,3,5-tris(bromomethyl)-2,4,6triethylbenzene ( $22.8 \mathrm{~g}, 51.7 \mathrm{mmol}, 97 \%$ ) as a white solid. In a second step, to a suspension of potassium phthalimide (8.4 g, $45.4 \mathrm{mmol})$ in dry DMSO $(75 \mathrm{~mL}) \quad 1,3,5-$ tris(bromomethyl)-2,4,6-triethylbenzene $(5.0 \mathrm{~g}, 11.3 \mathrm{mmol})$ was added at room temperature, under nitrogen atmosphere. The reaction mixture was heated to $84^{\circ} \mathrm{C}$ for $8 \mathrm{~h}$; the solution obtained was cooled to $0{ }^{\circ} \mathrm{C}$, and the formation of a white solid was observed. After $1 \mathrm{~h}$ at room temperature, the solid was filtered off, dissolved in water $(100 \mathrm{~mL})$, and extracted with $\mathrm{CH}_{2} \mathrm{Cl}_{2}(2 \times 100 \mathrm{~mL})$. The combined organic layers were washed with water $(2 \times 50 \mathrm{~mL})$, dried over $\mathrm{Na}_{2} \mathrm{SO}_{4}$, and concentrated to give 1,3,5-Tris(phthalimidomethyl)-2,4,6triethylbenzene $(4.88 \mathrm{~g}, 7.63 \mathrm{mmol}, 67 \%)$ as white crystals. Then the mother liquor was poured into water $(200 \mathrm{~mL})$, and the white precipitate formed was filtered off. The solid was dissolved in $\mathrm{CH}_{2} \mathrm{Cl}_{2}(100 \mathrm{~mL})$, washed with water $(3 \mathrm{x} 50$ $\mathrm{mL}$ ), and dried over $\mathrm{Na}_{2} \mathrm{SO}_{4}$. Evaporation of the organic solvent gave a crude $(2.69 \mathrm{~g})$ which was purified by flash column chromatography on silica gel (hexane/EtOAc, 1/1, $\mathrm{v} / \mathrm{v})$ to afford a second amount of 1,3,5Tris(phthalimidomethyl)-2,4,6-triethylbenzene (1.45 g, 2.27 $\mathrm{mmol}, 20 \%)$. In the thrid step, to a suspension of $1,3,5-$ Tris(phthalimidomethyl)-2,4,6-triethylbenzene (3.2 g, 5.0 $\mathrm{mmol})$ in $\mathrm{EtOH} /$ toluene $2: 1 \mathrm{v} / \mathrm{v}(18 \mathrm{~mL})$ hydrazine hydrate $(0.98 \mathrm{~mL}, 30.8 \mathrm{mmol})$ was added at room temperature under nitrogen atmosphere. The reaction mixture was refluxed for $20 \mathrm{~h}$, and during this time a white solid was formed. The reaction was cooled to room temperature, and the white solid was filtered off, dissolved in a $40 \%$ aqueous solution of $\mathrm{KOH}$ $(120 \mathrm{~mL})$, and extracted with $\mathrm{CHCl}_{3}(3 \times 150 \mathrm{~mL})$. The combined organic layers were washed with water $(3 \times 150$ $\mathrm{mL}$ ) and dried over $\mathrm{Na}_{2} \mathrm{SO}_{4}$. Evaporation of the organic solvent gave $2(0.973 \mathrm{~g}, 3.90 \mathrm{mmol}, 78 \%)$ as a white solid. Mp $138-140{ }^{\circ} \mathrm{C} ;{ }^{1} \mathrm{H}$ NMR $\left(0.1 \mathrm{~mol} \mathrm{dm}^{-3}\right.$ in $\left.\mathrm{CDCl}_{3}, 200 \mathrm{MHz}\right)$ $\delta: 3.87(\mathrm{bs}, 6 \mathrm{H}), 2.82(\mathrm{q}, 6 \mathrm{H}), 1.26(\mathrm{bs}, 6 \mathrm{H}), 1.23(\mathrm{t}, 9 \mathrm{H}) .{ }^{13} \mathrm{C}$ $\mathrm{NMR}\left(\mathrm{CDCl}_{3}, 50 \mathrm{MHz}\right) \delta: 140.3,137.4,39.6,22.5,16.8$.

Synthesis of receptor 3: A mixture of $2(26.8 \mathrm{mg}, 0.106$ $\mathrm{mmol})$ and fluorescein isothiocyanate $(125 \mathrm{mg}, 0.32 \mathrm{mmol})$ was dissolved in dichloromethane $(20 \mathrm{~mL})$. Then, triethylamine $(1.5 \mathrm{~mL}, 10.7 \mathrm{mmol})$ was added and the mixture refluxed for 24 hours. After cooling to $25^{\circ} \mathrm{C}$, the solvent was removed in vacuo giving a residue, which was purified by silica column (increasing polarity from ethyl acetate/hexane, $10 / 1, \mathrm{v} / \mathrm{v}$ to ethyl acetate/hexane, $20 / 1, \mathrm{v} / \mathrm{v}$ ) to yield receptor 3 as an orange solid (42 mg, $0.03 \mathrm{mmol}, 28 \%)$. ${ }^{1} \mathrm{H}$ NMR $\left(\mathrm{DMSO}_{6}, 300 \mathrm{MHz}\right) \delta: 10.2(\mathrm{~s}, 6 \mathrm{H}), 8.25(\mathrm{~s}, 3 \mathrm{H}), 8.10(\mathrm{~s}$, $3 \mathrm{H}), 7.75(\mathrm{~d}, 3 \mathrm{H}), 7.21$ (d, 3H), $7.14(\mathrm{~d}, 3 \mathrm{H}), 6.62(\mathrm{dd}, 3 \mathrm{H})$, $6.58(\mathrm{dd}, 3 \mathrm{H}), 5.24(\mathrm{~d}, 3 \mathrm{H}), 5.12(\mathrm{~s}, 3 \mathrm{H}), 4.67(\mathrm{~s}, 6 \mathrm{H}), 2.95(\mathrm{q}$, $6 \mathrm{H}), 1.15$ (t, 9H). MS (FAB): m/z $1415\left(\mathrm{M}^{+}\right)$.

13. Huo, F-J.; Yin, C-X.; Yang, Y-T.; Su, J.; Chao, J-B.; Liu, DS. Anal. Chem. 2012, 84, 2219-2223. 